\title{
Ethnomedicinal Knowledge among the M'ranaos in Baloi, Lanao Del Norte, Philippines
}

\author{
Nafisah M. Abdulrachman ${ }^{\# 1}$, Aisha M. Ali ${ }^{\# 2}$, Hanifa M. Maurac ${ }^{\# 3}$, Annabella G. Villarino ${ }^{\# 4}$ \\ \#1, \#2,\#3, \#4 Graduate School, Mindanao State University \\ MSU Campus, Marawi City, Philippines
}

\begin{abstract}
Plants are utilized as traditional medicines since time immemorial. However, the dilemma of losing this knowledge is real because of poor documentation evidenced by the relatively few studies conducted coupled with rapid urbanization especially in the Philippines. It is imperative for ethnomedicinal knowledge especially of the M'ranao tribe in Baloi, Lanao del Norte to be conserved, hence this study. Ethnomedicinal data were collected from semi-structured interviews of 30 informants and analyzed qualitatively and quantitatively. Moreover, transect walk was performed to locate the frequently used medicinal plants. This study documented seventy eight (78) species of medicinal plants belonging to 36 families used for the treatment of various ailments belonging to 14 out of 16 human disease categories. The most important medicinal plant with a Use Value (UV) of 0.43 is Mingeyak (Salvia plebeian). There were fifty five (55) floral species found to have 100\% Fidelity Level (FL) value. An Informant Concensus Factor (ICF) of 1.00 for disease Category 2, Category 3, and Category 16 indicates that there was a high degree of agreement among informants on how to treat cancer, anemia, and intestinal toxicity respectively. Leaves (63\%) were the most frequently used plant part and decoction (41\%) was the most common way of preparation. Internal application (77\%) was the most recurrent way of plant administration to the ailing body. Herbs (47\%) as medicine were the most frequently used plant habit. Qualitative investigation resulted to the identification of M'ranao traditional beliefs and practices in utilizing medicinal plants which include the time of collection, the number of plant organ collected (e.g. pito-pito) and the ways of conserving herbal plants for continuing sustainability. This study further revealed that the M'ranao tribe of Baloi has a rich floral resources use as medicines which could be further investigated for pharmacological properties to improve health care for various illnesses.
\end{abstract}

Keywords: Ethnomedicinal Knowledge, Medicinal plants, M'ranao tribe

\section{INTRODUCTION}

Plants with medicinal properties have always been the heart of man's interest in his quest for drugs for various ailments and in the promotion of good health. Since the ancient times, people have been utilizing medicinal plants for healing. Over the years, even with the many great advances made in treating and curing different diseases (1), traditional herbal remedies are still widely used by people all over the world (2). Recently, because of the greater demand for the utilization of plants in the field of medicine, bridging the gap between traditional beliefs and practices on medicinal plants and the modern science serves as today's innovation in the world of medicine. Medicinal plants utilized by indigenous people have taken much attention in modern medical practices. Balangcod and Balangcod (2011), noted that there is a continuing quest for the discovery of the new clinical effects of traditionally used medicinal plants.

The irony however, is that whilst Western countries are feasting on the utility of traditional medicines and subjecting them to intensive scientific research and product development, the Philippines however, is still struggling on how to document the local communities indigenous knowledge amidst threats of desertion and extinction of the floral resources, Moreover, these unexplored knowledge are confined among older generation transferred primarily through oral communication (4) and when the carriers of the said knowledge demise, then the said knowledge is lost forever (5). As Balangcod and Balangcod (2011) resonates, the knowledge that is trapped in the older generation is not documented, and the problems on deforestation and land conversion persist, plants and associated knowledge will be irretrievably lost, hence the urgent necessity of conducting this documentation.

\section{A. Statement of the problem}


The conservation of ethnomedicinal knowledge is becoming increasingly important, thus this research aimed to document the use of medicinal plants and the associated practices in the utilization of the said plants in Baloi, Lanao del Norte by, (a) enumerating the various plants utilized to treat diseases, (b) determining the disease category/categories treated by the mentioned plants, (b) which organ or parts of the plant is used, (c) the modes of preparation of the plant to be used as medicine, (c) frequency of use., (d) identify the medicinal plants used frequently and (e) calculate for the informant concensus factors.

\section{B. Significance of the Study}

Documentation of the traditional ethnomedicinal knowledge of the M'ranaos in Baloi, Lanao del Norte hopes to provide information on how rich is the traditional knowledge of the local people. This research also hopes to provide a list of medicinal plants to the scientific community which could further investigate the enumerated plants as potential sources of novel drugs.

Moreover, documenting indigenous plants with medicinal uses and the associated ethnobotanical knowledge can be a basis for the formulation of conservation measures for the sustainable utilization of the flora for our future generation (Arquion, et. al., 2015).

\section{METHODS}

\section{A. Research Setting}

This study was conducted last July 2018 in Baloi, located in the geographical coordinates $8007^{\prime}$ N 124013 '

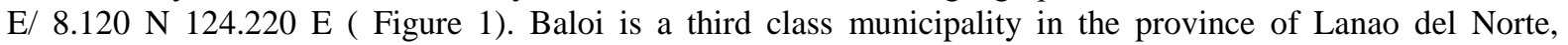
Philippines with a total population of 58, 383 according to the 2015 census. Of the 21 political barangays in Baloi, four (4) barangays were selected through stratified random sampling, namely; Barangay Bangko, Lumbac, Nangka and Landa,

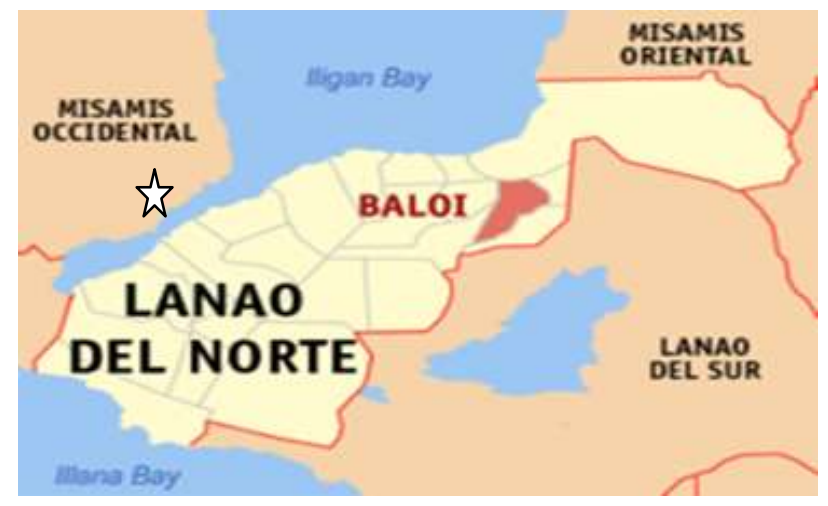

Fig 1: Map of the location of the study site, Baloi, Lanao del Norte .

\section{B. Study Population}

Data were collected from thirty $(\mathrm{N}=30)$ informants which are traditional healers or pamomolongs knowledgeable on the different medicinal plants utilized to treat various ailments. Around 5 to 10 informants per barangay were chosen. Majority $(70 \%)$ of the informants were housewives whose educational attainment is until the primary level only.

\section{Data Collection}

Prior to the conduct of the study, permission was first obtained from the Municipal office and the barangay chairman of the four (4) selected barangays. Data were collected employing a semi-structured interview from 30 informants which were first requested to sign an informed consent. The interview questions were translated into the M'ranao dialect

The interview questions include the demographic profile, knowledge on ethnomedicinal plants along with the associated beliefs and practices, the M'ranao local name of the plant, ailment treated, plant part used, method of preparation, and method of application. Interviews were done in conjunction with a field visit to allow collection 
of plant specimens for taxonomic identification. Voucher specimens were also collected and preserved by immersing them in denatured alcohol. Identification of the specimens was done by comparing the specimens with the List of Medicinal Plants of the Philippines, referral to experts and other plant databases.

A transect-walk was also performed in the four (4) selected barangays (Bangko, Lumbac, Nangka and Landa) to locate the medicinal plants. A GPS software was used to trace the pathway taken throughout the transect walk and to plot the approximate location of the most frequently used medicinal plants.

\section{Data Analysis}

The collected data was analyse using the quantitative indices namely; Relative frequency, Use Report, Use Categories, Use Value, Informant Consensus Factor and Fidelity Level. The Relative Frequency refers to the rate of occurrence which was used to describe the habit of growth of the medicinal plants, most common plant parts used, most common methods of preparation, and application. Diseases mentioned were also categorized based on the International Classification of Diseases (ICD-10) by the World Health Organization (WHO. While the Use Value is the ratio of the number citations per species (U) to the number of informants $(\mathrm{N})$ and is given by the formula: $\mathrm{UV}=\mathrm{U} / \mathrm{N}$. High UV indicates high use-reports for a plant implying its relative importance to the local community. Low UV indicates few reports related to its use. The Informant Consensus Factor, on the other hand, is evaluated using the formula: $\mathrm{FIC}=(\mathrm{Nur}-\mathrm{Nt}) / \mathrm{Nur}-1$ : where Nur is the number of use reports in each category and $\mathrm{Nt}$ is the number of species used for a particular category by all informants. The maximum value for this index is 1 , which imply that the informants completely agree that the particular species cited could cure a particular ailment. A value of 0 , the minimum value, means that there is no exchange in information among the informants about plants.

\section{RESULTS AND DISCUSSION}

This study revealed that M'ranao traditional healers of Baloi were utilizing seventy eight (78) species of medicinal plants belonging to 36 families in treating 47 different ailments (Table 1). Family Asteraceae and Poaceae recorded the highest number of 7 medicinal plant species each, followed by and Euphorbiaceae with 6 recorded species and Family Lamiaceae with 5 species. Dominance of medicinal plant species from the abovementioned families could be attributed to their wider distribution and abundance in the flora area (3). Moreover, the wide utilization of species from these families might relate to the presence of effective bioactive ingredients against the ailments mentioned (4).

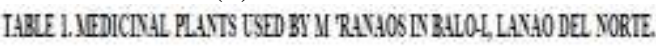

\begin{tabular}{|c|c|c|c|}
\hline FAIIYNAME & Local Kant & Scienfix Tiant & Linaats Tinit \\
\hline ACANTHACEAE & Whan a mats & 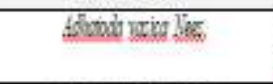 & $\begin{array}{l}\text { Cough Fra, Eas tepon dine } \\
\text { bis }\end{array}$ \\
\hline AMARAVIHACEAE & Srmo Pegays & 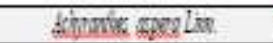 & Lat of mpete fis \\
\hline AMLRTLOACEAE & Gisi & dir ghoworn & bxy pases \\
\hline ANACAQDAACEAE & Ingeg & 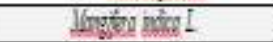 & Irgily dand isr (southy) \\
\hline \multirow{2}{*}{ ANWOAACAE } & Ans & drove symore? & Furdabeth \\
\hline & Ghan & froger monel & Inparain ac boty pans \\
\hline APHLCEE & Ingli he & Coxhis sinit L & Ferer \\
\hline \multirow{2}{*}{$\begin{array}{l}\text { APOCARCEAE } \\
\text { ARAIACEAE }\end{array}$} & Jaglabs? & 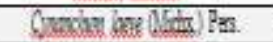 & Icisht fan ad nowd \\
\hline & Igin & 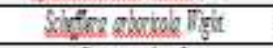 & Fert \\
\hline \multirow{3}{*}{$\frac{\text { APECACEAE }}{\text { ASPARAGACELE }}$} & $\operatorname{Mrog}$ & Cocer acisin $L$ & \\
\hline & Imana & dras atein I & Atitain \\
\hline & Diazph & 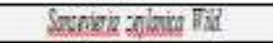 & Bleing \\
\hline \multirow{7}{*}{ ASTERACEAE } & Sementon & 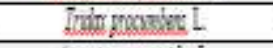 & Eser at aoch \\
\hline & Iescizizi & Agnim anzixis L. & mul ad dosanted \\
\hline & Sankruxgen & Strusin ngat L & Ean ad binnd yin \\
\hline & Teasyz & Conanksan sidav I & 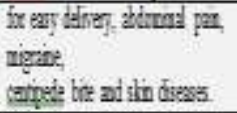 \\
\hline & Motiang & ferrotich quinive & being frec ad urui \\
\hline & Inta & 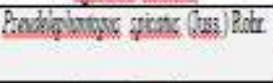 & 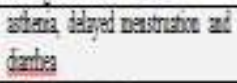 \\
\hline & tonges & Intosesing tin. & Daged uzsinabo \\
\hline
\end{tabular}




\begin{tabular}{|c|c|c|c|}
\hline \multirow{4}{*}{ WORACEAE } & Back & 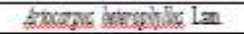 & Alegge: \\
\hline & Wagasced & Frar sestixs & 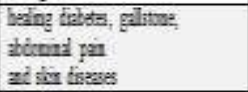 \\
\hline & Kernasi & 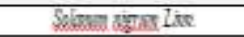 & Mesles \\
\hline & Whas & There righ Les: & Bove fractre \\
\hline MORLGGACEAE & Réanguze & 1hringr oberen & Anam \\
\hline MUSACEAE & Therates & Ifes antis & 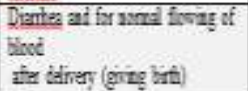 \\
\hline JOSACEAE & Snging & 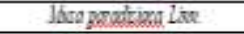 & Asterna \\
\hline \multirow{3}{*}{ MIPTACEAE } & Borkar & Pixis guing I & $\begin{array}{l}\text { Tsed fix danten thassi, } \\
\text { frtlane ad nuonds }\end{array}$ \\
\hline & Talis & Sogign purs & dathen ani vke \\
\hline & 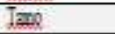 & 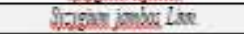 & Asteria \\
\hline \multirow{3}{*}{$\begin{array}{l}\text { OXAIIDACEAE } \\
\text { PAPAVERACEAE }\end{array}$} & Ks: & Osic posals & reang frex far ifiar ad bdda \\
\hline & \multirow{2}{*}{$\begin{array}{l}\text { Binting } \\
\text { Kapankings }\end{array}$} & 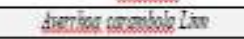 & Ther ad frownontel par \\
\hline & & 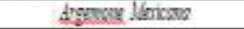 & Wirad \\
\hline PAPLIONACEAE & Gethes & Crint crixt Im & Entwandxu Bash \\
\hline PPERACEAE & Sanst & Pyg kig L & boing attinis \\
\hline \multirow{8}{*}{ POACEAE } & & & \\
\hline & Bang & 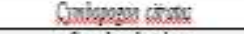 & Hyperasiva \\
\hline & Bersula & Gowden dexths & lat of alcin \\
\hline & Gákan gass & 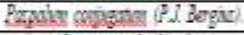 & woud ad delary restration \\
\hline & 3 masage & Ioxsd gintios? & 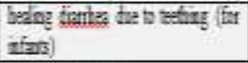 \\
\hline & Panks=a & Evirise nould & cos: ad attain \\
\hline & Lays & Opresstiva I & Hypetasino \\
\hline & Paits & Gromsation I & $\begin{array}{l}\text { dabots, dodxund pain and } \\
\text { nad }\end{array}$ \\
\hline POXIEDERIACEA & Gabi-ghi & Jorocheris acsose & Worad \\
\hline \multirow{3}{*}{$\begin{array}{l}\text { RUTACEAE } \\
\text { SAROTACEAE }\end{array}$} & Mariant & Otie ratichist Bing & bealug uigraine leabate \\
\hline & $P g$ & Coxp nonix 2 & Artanis \\
\hline & Apd & Crogeble crivis I & $D$ ancies \\
\hline \multirow{3}{*}{$\begin{array}{l}\text { SOLANACEAE } \\
\text { VERBENACEAE }\end{array}$} & Laget & Jimfing hbass & Edans \\
\hline & Zamelanatsal & 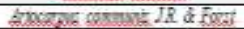 & Srathe \\
\hline & Gasktres & Lation gaves & Couph \\
\hline \multirow{3}{*}{ ZNGIBERACEAE } & Lro a pagsia & Zrget sfivol & body deaning \\
\hline & Xalasg & Garme bugh & 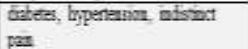 \\
\hline & Thid Inex & Covano anowati & beang atrits \\
\hline
\end{tabular}

\begin{tabular}{|c|c|c|c|}
\hline BSGNOXLACEAE & VIIrstocis & Shavos haves Lum & Fera \\
\hline CARLCACEAE & Kepuz & Carxesasga $\mathrm{L}$. & bypateain ctut ind hid lever \\
\hline CBASSILACEAE & Desirs? & 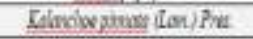 & Feve \\
\hline CYPERACEAE & Thi & Grovobericts & pxpant watht \\
\hline DIOSCOREACEALE & Avgubiands & Drexweat & Wintorat \\
\hline \multirow{6}{*}{ EUPGORBINCEAE } & Bnandi & Motiperivents & topateavin at dratha \\
\hline & Kanzso-musa & dxtron anel & $\begin{array}{l}\text { heaint hyeeraico ad bos: } \\
\text { buctus }\end{array}$ \\
\hline & Kanos: & 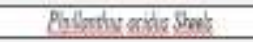 & Counh \\
\hline & 70 atós & 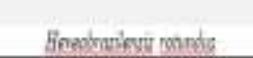 & bealy zke \\
\hline & Jinota & Lophersives L & deagutieret \\
\hline & Aler & 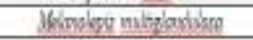 & Abdxainal pin \\
\hline FABACEAE & Natrectos & 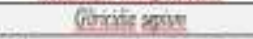 & beaing thtins: \\
\hline GRAXIKEAE & Seroddat2 & 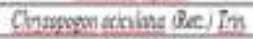 & Fet fever aed riond \\
\hline GUTIIFERAE & Nazzate & Guctan aogosus I & baint Gyartery ad inthess \\
\hline \multirow[b]{5}{*}{ LAXIACEAE } & Gerilits & Gulvegtene Pon & Fintlast \\
\hline & Kund & Coinu rovinas Batk & Couth \\
\hline & Lescal & Tre nosinio & baling oush \\
\hline & Pre & Gigatitivizar & coceth is hictineil \\
\hline & Xasera & Satiopking. & braing fese \\
\hline LAUBACEAE & Xesde Alcobde & Pesolinenass & $\begin{array}{l}\text { Dientes afitain ad lats of } \\
\text { prasing }\end{array}$ \\
\hline LEGUMNOSAE & Kape & Mroaa purion Limt & Toud \\
\hline LITERACEAE & Batke & Loveatomin cricias & Conritice \\
\hline \multirow[b]{2}{*}{ MALVACEAE } & Gonach & 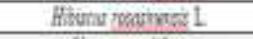 & Bails \\
\hline & Dikgars & 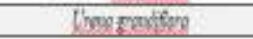 & Attuaik \\
\hline
\end{tabular}


Figure 1 showed that most of the frequently used medicinal plants are located in close proximity to the informants. Some of the plants were cultivated by the informants for easy access whenever they needed the plants.

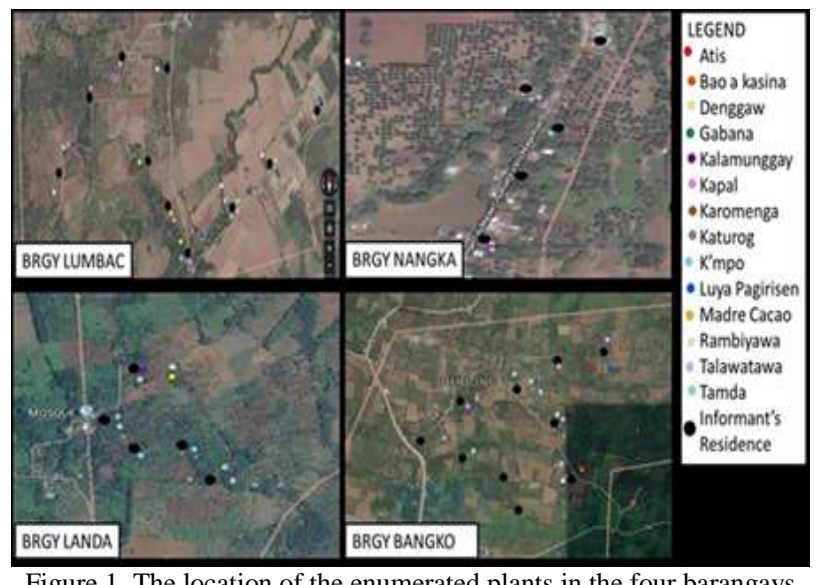

Characterization of the plant habit of the enumerated medicinal plants revealed that out of 68 plants, herbs $(47 \%)$ were the most numerous ( Figure 2). Grasses like kapal, g'nda (Allium schoenoprasum), and rambiyawa (Eleusine indica) were classified as herbs. Thirty-three percent of the mentioned plants were trees, followed by shrubs (17\%) and vines (3\%). Herbs are small in terms of size, hence collection and processing is less tedious. The finding agrees with the general pattern of dominance of herbaceous species seen in most medicinal plant inventories (7-12).

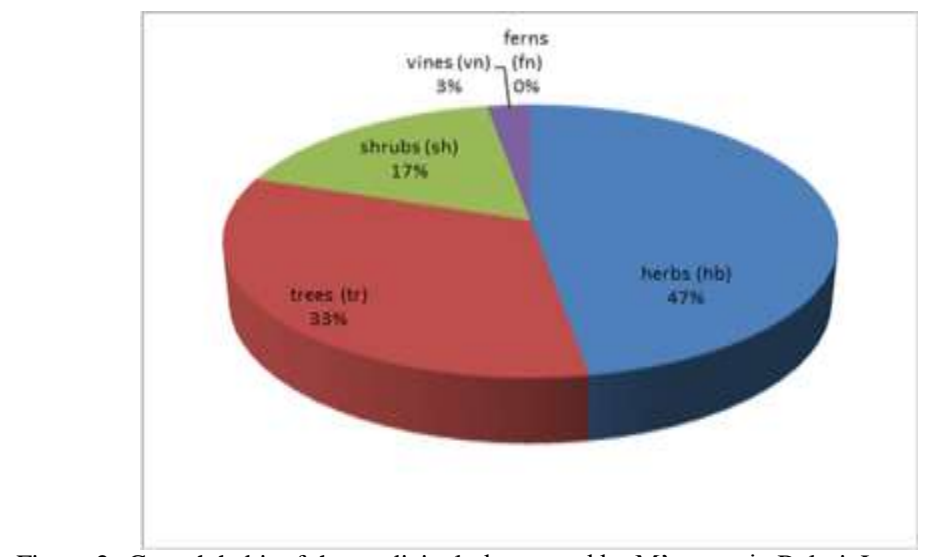

Figure 2. Growth habit of the medicinal plants used by M'ranaos in Balo-i, Lanao del Norte

The leaves, roots, fruits, bark, stem, seeds, whole plant, flower, latex, sprouted grain and rhizome were the medicinally important plant parts cited by the informants. The most frequently used medicinal plant parts were the leaves $(63 \%)$ followed by root $(16 \%)$ and the whole plant $(12 \%)$ as shown in Figure 3. 
Figure 3. Plants parts used by M'ranaos in Balo-i, Lanao del Norte for traditional remedies: Bk, Bark; Fl, flower; Fr, Fruit; Lf, Leaf; Rt, Root; Gr, grain; St, stem; Lx, Latex; Spr, Sprouted; Rz, Rhizome; Wh, whole plant

The recorded methods of preparation includes: burning, chewing, decoction, extraction, pounding, smoked, and mixing with water. The most common preparation is decoction (41\%) while some plants $(8 \%)$ are utilized unprocessed (Figure 4). Moreover, the medicinal plant preparations were administered either internally (79\%) or externally (Figure 5). The dominant use of medicinal plant decoctions for various ailments might be related to their proven effectiveness over many years of trial. Decoction was also reported as one of the major way of remedy preparation in ethnomedicinal inventory of other socio-cultural groups in other countries $(5,6)$.

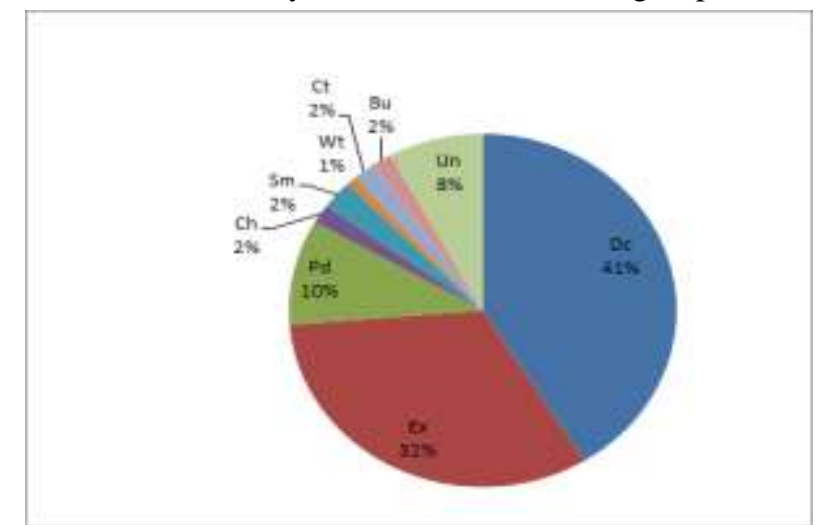

Figure 4. Methods of preparation of medicinal plants as practiced by M'ranaos in Balo-i, Lanao del Norte. Bu, burning; Ch, chewing; Dc, decoction; Ex, extraction. Pd, pounding; Sm, Smoked; Wt, mix with water; Un, Unprocessed.

Plants with the highest use values were mingeyak (Salvia plebeia) with UV=0.43 for disease category 14 , followed by kapal (Coleus aromaticus Benth.) and talawatawa (Euphorbia hirta L.) with UV=0.37 for category 8 and category 1 respectively. The medicinal plant, tamda (Pseudelephantopus spicatus (Juss.) Rohr.) for category 9 had a UV=0.23 The plants with high use values are indicative of species with many use reports and are considered important by the traditional healers.

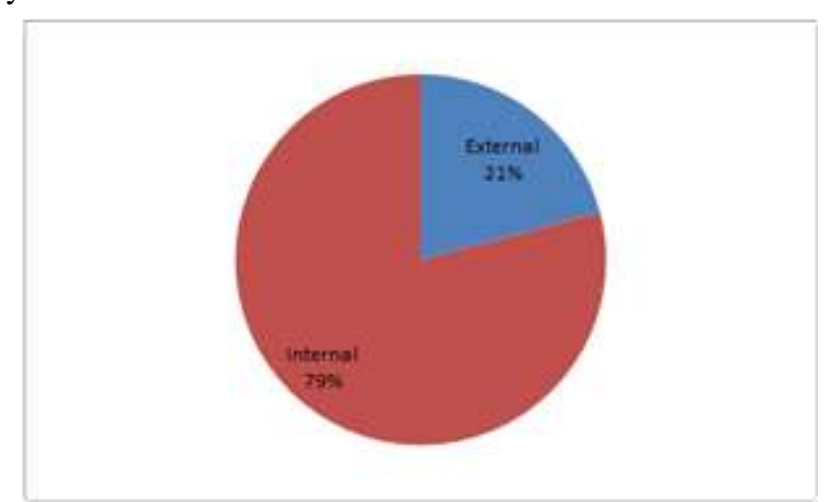

Figure 7. Methods of administration of medicinal plants practiced by M'ranao in Balo-i, Lanao del Norte. 
There were fifty-five (55) species found to have $100 \%$ FL values namely; mingeyak (Salvia plebeia) for the treatment of fever, Gabana (Annona muricata L.) for the treatment of hypertension had 85.71 FL values. A high FL values indicate that the plants mentioned have specific use as mostly preferred by the informants.

\section{CONCLUSION}

This research revealed that M'ranaos of Baloi, Lanao del Norte possess rich ethnomedicinal knowledge evidenced by their dependence on naturally growing plant species in treating different ailments. Plants in their immediate surrounding are their immediate source of alternative medicine since access to healthcare facilities is limited.

\section{ACKNOWLEDGEMENT}

We are grateful to ATIEE for this opportunity to publish. Thank you also to our informants for the eagerness to share your ethno medicinal knowledge.

\section{REFERENCES}

[1] Snow, K. The origins of alternative medicine. Retrieved from ww.filipinoherbshealingwonders.filipinovegetarianrecipe.com. 2015.

[2] Morilla, L. J., Sumaya, N. H., Rivero, H. I., \& Madamba, M.R.Z. Medicinal plants of the Subanen in Dumingag, Zamboanga del Sur, Philippines. Paper presented at the International Conference on Food, Biological and Medical Sciences, Bangkok, Thailand, 2014.

[3] Balangcod, J.D., \& Balangcod, A. K.. Ethnomedicinal knowledge of plants and healthcare practices among the Kalanguya tribe in Tinoc, Ifugao, Luzon, Philippines. Indian Journal of Traditional Knowledge, 10(2), 227-238, 2011.

[4] Favor, C.. Ethnobotany of plants in Tagkawayan: Input for information communication media on medicinal uses of plants. Philippine Journal of Agricultural Economics, 1(1). doi: https://doi.org/10.7719/pjae.v1i1.486. 2017.

[5] Arquion, R.D., Galanida, C.C., Villamor, B., \& Aguilar, H.T. Ethnobotanical study of indigenous plants used by local people of Agusan del Sur, Philippines. Asia Pacific Higher Education Research Journal, 2(2), 91-101, 2015.

[6] Sori T, Bekana M, Adugna G, Kelbessa E. Medicinal plants in the ethnoveterinary practices of Borana pastoralists, Southern Ethiopia. International Journal of Applied Research in Veterinary Medicine, 2:220-225, 2004.

[7] Teklehaymanot T, Giday M. Ethnobotanical study of medicinal plants used by people in Zegie Peninsula, Northwestern Ethiopia. J Ethnobiol Ethnomed, 3:1, 2007.

[8] Gazzaneo LRS, Lucena RFP, Albuquerque UP. Knowledge and use of medicinal plants by local specialists in a region of Atlantic Forest in the state of Pernambuco (Northeastern Brazil). J Ethnobiol Ethnomed, 1:9, 2005.

[9] Giday M, Asfaw Z, Woldu Z. Ethnomedicinal study of plants used in Sheko ethnic group of Ethiopia. J Ethnopharmacol , 132:75-85, 2010.

[10] Yineger H, Kelbessa E, Bekele T, Lulekal E. Ethnoveterinary medicinal plants at Bale Mountains National Park, Ethiopia. J Ethnopharmacol , 112:55-70, 2007.

[11] Giday M, Asfaw Z, Elmqvist T, Woldu Z. An ethnobotanical study of medicinal plants used by the Zay people in Ethiopia. J Ethnopharmacol , 85:43-52, 2003.

[12] Muthu C, Ayyanar M, Raja N, Ignacimuthu S. Medicinal plants used by traditional healers in Kancheepuram District of Tamil Nadu, India. J Ethnobiol Ethnomed , 2:43, 2006.

[13] Tabuti JRS, Lye KA, Dhillion SS. Traditional herbal drugs of Bulamogi, Uganda: plants, use and administration. J Ethnopharmacol , $88: 19-44,2003$.

[14] Mesfin F, Demissew S, Tekelaymanot T. An Ethnobotanical study of medicinal plants in Wonago Woreda, SNNPR, Ethiopia. J Ethnobiol Ethnomed , 5:28, 2009. 